Meteorologie, I88I, xvi. 369 ; Naturforscher, I882, No. 5.) During Baron Nordenskjöld's wintering nerr Pitlekaj, on the Cape Serze Kamen (near Behring Strait) in $1878-79$, an ice-fog was formed by the north wind predominating there during the cold season, by which the aqueous vapour.from Polynjen was blown over the cold mainland. This ice-fog rendered the air opaque to such an extent that it was found necessary, in order to find the way, to span a rope from the ship to the observatory which was erected not far off on the shore.

Heidelberg, February I I

HERMANN KOPP

\section{Earthquake in the Andaman Islands}

I SEE among the Notes in your last issue (p. 325) that there has been widespread seismic disturbance in Asia, including Ceylon, but unfortunately in no instance is the date given, which would have added very greatly to the value of the record. It may be interesting to give an extract from a letter I have just received from my brother, Mr. Harold Godwin-Austen, from Port Blair, Andaman Islands, which very probably was con. nected with the disturbance in Ceylon, and if so, it covered a very considerable area of the earth's surface, the distance being about 750 miles between the two places : - "Port Blair, January 2. - We had a very bad earthquake here on December 31, I88I, at $7.52 \mathrm{a} . \mathrm{m}$. I thought the place was going to pieces. There has been a good deal of damage done to work and pucca (brick) buildings, and we had five high and low tides in three hours after the shock, and the sea did not quiet down all day. Since then we have had two or three slight shocks."

Deepdale, Reigate, February 9 H. H. Godwin.AUsten

\section{The "Overflow Bugs" in California}

THE following experience from one of my correspondents, Mrs. A. E. Bush, of San José, Califorria, is, I think, well worth publishing, as showing how Ground-beetl s may be so numerous as to become a nuisance to $\mathrm{mm}$, the Carabidx generally being indirectly beneficial to him by devouring plant-feeding species. The insect popularly denominated. "Overfluw Bug" in California is the Platynus maculicollis, Dej.

Washington, D.C.

$$
\text { C. V. RiLey }
$$

"We lived in Fresno Co. two years, in the north-eastern part, and in the foot-bills of the Sierra Nevada. It is hot and dry there; no trees and many rocks where we ware; thermometer ranging from $96^{\circ}$ to $108^{\circ}$ for about three months. In June and July, when hottest and driest, the "overflow bugs" filled the air between sunset and dark. You could not with safety open your mouth. They would light all over your clothes; they filled the house; they swarmed on the table, in the milk, sugar, flour, bread, and everywhere there was a crevice to get through. Take a garment from the wall, and you could shake out a cupfull. It was a veritable plague. In a shed where the boards had shrunk and the cracks been battened, the spaces between the shrunken boards were packed full. They were flying for about two weeks, and then they disappeared mo tly or they did not fly much, but were hidden under papers, clothing, and every avail. able place. In November, before the rains, they spread around, but not to fly; make a light in the niyht, and you would see the floor covered ; lift up a rug, and the floor under would be black, and they would go scattering away for some other hiding-place. I had occasion to take up a floor board after tliey had apparently disappeared, except stragglers. The house was upon underpinning two feet or more from the ground. When the board was raised, there were the 'overflow bugs' piled up against a piece of underpinning, making such a pile as a half bu.hel of grain would make. They were all through the foot-hills the same, and much the same in I.os Angelus, about Norfolk, but they did not fly much in the latter place. In Los Angelos they seemed to be wor: e before the 'Santa Annas,' a hot wind from the desert filling the air with sard; and though the chickens were ever so hungry for insects, they would not eat the "overflow buss.' In the night you put up your hand to brush one from your face, and then you get up for soap and water to cleanse your hand. In the murning, if you put on garment.s without shaking, you get them quickly off and shake them."

\section{Solar Halo}

WE were favoured here on the 16 th inst. with a view of a rather unusual phenomenon. Shortly after 8 a.m., the sky being for the most part clear with detached masses of fleecy clouds towards the south, two mock suns appeared, one to the west very brilliant, the other rather fainter, and of a crimson shade at times. The halo was visible for a little distauce near the western one, whicb, with the bar of light from the sun extending along the bank of cloud beyond, formed a perfect cross. They gradually waned, the eastern one, however, becoming once or twice more brilliant, till a little after Io, when the sky grew overcast and they disappeared.

Felsted, Essex

W. F. Evans

\section{Auroral Display}

AN auroral display was observed here last evening between $7 \mathrm{~h}$. and $8 \mathrm{~h}$. The sky was partially overcast during a portion of the time, but it cleared about $7 \mathrm{~h}$. Iom., when the northern quarter was lighted up by a bright glow of an aqua-marine line. Only three faint streamers were remarked. They were of a creamy-white colcur, and extended from the horizon in the direction of the magnetic north nearly to the zenith. Examining the auroral light with a direct-vision spectroscofe by Hilger, I saw one remarkably distinct line, which was estimated to occupy the position of the characteristic line observed by Ångström and others, between D and E. No other lines were visible.

Bedford, February 2I THOS. GWYN ELGER

\section{A Plea for Jumbo}

WILL you open your columns to a short but earnest plea for poor Jumbo, of the Zoolugical Gardens? No one can read the description of the attempts made to remove him without feeling that it would be a disgrace to English lovers of animals to let him be transported. To outsiders it is a mystery that $\mathrm{Mr}$. Barnum should have succeeded in purchasing him, and if some means are not discovered of saisfying Mr. Barnum's claims without doing violence to the public sentiment of humanity, it will be a cause of indignation to many of us. You should hear my wife talk about the matter, but of course she is only a woman, she is certainly not a "Fellow." In this case, however it is possible that her womanly instinct is worth more respect than the motives which have led to the sale and purchase of our favourite quadrupedal fellow-citizen.

A. R.

\section{THE CHEMISTRY OF THE ATLANTIC}

$$
\text { J. }
$$

I $\mathrm{N}$ this work are collected and discussed the results of the chemical investigations on the nature of the water of the North Atlantic, made during the Norwegian expeditions of the summers 1876,1877 , and 1878 . The contents of the volume are divided into three chapters-I. On the Air in Sea Water; II. On the Carbonic Acid in Sea Water; and III. On the Amount of Salt in the Water of the Norwegian Sea. It is therefore wholly concerned with the chemistry of the water; chemical researches in other directions are promised for a future volume. Although the subject is thus restricted, there is abundant matter of the greatest interest both from a chemical and from a geographical point of view.

Apart from isolated experiments, the first occasion on which the gaseous contents of sea-water were the object of systematic and successful study was during the German expeditions to the Baltic and the North Sea in $187 \mathrm{r}$ and 1872 in the Pomerania. In the Lightning and the Porcupine attempts had been made to examine the water in this direction, but the results were not satisfactory. In order to determine the gaseous contents of a sample of water it is necessary first to eliminate and separate the gas from the water, and then to analyse it; and these form two distinct operations-one, the former, of which can be carried out perfectly on board ship; the other requires the steadiness of a shore laboratory. On board the Lightning and the Porcupine the mistake was made of attempting the analysis as well as the extraction of the air on board.

I The Norwegian North Atlantic Expedition, $1876-78$. Chemistry. By 